\title{
Laporan Kasus: Kegoyangan Gigi Pada Pasien disertai Diabetes Mellitus
}

\section{(A Case Report: Tooth Unsteadiness in Patients with Diabetes Mellitus)}

Pascalis Adhi Kurniawan', Rinawati Satrio²

1 Kedokteran Gigi, Universitas Jenderal Soedirman

2 Bagian Ilmu Penyakit Mulut, Kedokteran Gigi, Universitas Jenderal Soedirman

\begin{abstract}
Abstrak
Diabetes Mellitus adalah suatu gangguan metabolik yang ditandai dengan peningkatan kadar glukosa darah (hiperglikemia) akibat gangguan pada sekresi insulin dan kerja insulin. Diabetes mellitus (DM) merupakan suatu penyakit yang ditandai dengan kadar glukosa dalam darah yang tinggi, karena tubuh tidak dapat melepaskan atau menggunakan insulin secara adekuat. Terdapat banyak faktor yang menjadi pencetus atau yang memperberat periodontitis, di antaranya akumulasi plak, kalkulus (karang gigi), dan faktor sistemik seperti diabetes mellitus. Tujuan: Menjelaskan bahwa terdapat hubungan yang saling berkaitan erat antara peningkatan kadar glukosa darah yang tinggi dengan periodontitis. Deskripsi Kasus: Seorang wanita usia 77 tahun datang dengankeluhan gigi kiri atas goyang dan sakit saat makan. Pasien mengaku memiliki riwayat penyakit sistemik yaitu diabetes mellitus. Pemeriksaan intra oral didapati pada gigi 27 luksasi derajat 3, resesi gingiva $6 \mathrm{~mm}$, probing depth $4 \mathrm{~mm}$, debris di sekeliling gigi, oral hygiene cenderung buruk. Terapi yang diberikan berupa edukasi pengaruh diabetes mellitus terhadap gigi dan kondisi rongga mulut pada umumnya, serta pentingnya menjaga kesehatan dan konsumsi makanan agar kondisi gula darah tetap terkontrol. Kesimpulan:Penyakit periodontal dapat dipengaruhi oleh DM. Periodontitis merupakan salah satu manifestasi DM di rongga mulut. Keparahan periodontitis dapat terjadi akibat peningkatan kadar glukosa darah.
\end{abstract}

Kata kunci: Diabetes mellitus, gula darah, kegoyahan gigi

\section{Abstract}

Diabetes Mellitus is a metabolic disorder characterized by an increase in blood glucose levels (hyperglycemia) due to disturbances in insulin secretion and insulin action. Diabetes mellitus (DM) is a disease characterized by high blood glucose levels, because the body cannot release or use insulin adequately. There are many factors that trigger or aggravate periodontitis, including plaque accumulation, calculus (tartar), and systemic factors such as diabetes mellitus. Objective: To explain that there is a close relationship between elevated blood glucose levels and periodontitis. Case Description: A 77 year old woman presented with a loose left upper tooth and pain during eating. The patient admitted to having a history of systemic disease, namely diabetes mellitus. Intra oral examination was found on 27th grade 3 luxation, $6 \mathrm{~mm}$ gingival recession, $4 \mathrm{~mm}$ probing depth, debris around the teeth, oral hygiene tends to be poor. The therapy provided is in the form of education on the effect of diabetes mellitus on teeth and the condition of the oral cavity in general, as well as the importance of maintaining health and food consumption so that blood sugar conditions are controlled. Conclusion: Periodontal disease can be affected by DM. Periodontitis is one of the manifestations of DM in the oral cavity. The severity of periodontitis can result from an increase in blood glucose levels

Key words: blood glucose, Diabetes mellitus, tooth unsteadiness

Korespondensi (Correspondence) : Pascalis Adhi Kurniawan. Kedokteran Gigi, Fakultas Kedokteran, Universitas Jenderal Soedirman. Jl. Dr. Suparno - Purwokerto, 53122. Email: pascalis.adhi@gmail.com

Diabetes Mellitus adalah penyakit gangguan metabolisme karbohidrat dimana hormon insulin tidak bekerja sebagai mana mestinya. Insulin adalah hormon yang diproduksi oleh kelenjar pankreas dan berfungsi untuk mengontrol kadar gula dalam darah dengan mengubah karbohidrat, lemak dan protein menjadi energi. Diabetes Melitus atau penyakit kencing manis merupakan suatu penyakit menahun yang ditandai dengan kadar glukosa darah (gula darah) melebihi nilai normal yaitu kadar gula darah sewaktu sama atau lebih dari $200 \mathrm{mg} / \mathrm{dl}$, dan kadar gula darah puasa diatas atau sama dengan $126 \mathrm{mg} / \mathrm{dl}^{1}$

Diabetes Mellitus merupakan salah satu faktor predisposisi untuk terjadinya periodontitis. Kondisi Diabetes Mellitus dapat menyebabkan menebalnya pembuluh darah yang memperlambat aliran nutrisi dan produk sisa dari tubuh. Lambatnya aliran darah ini menurunkan kemampuan tubuh untuk memerangi infeksi, Hal ini memperberat infeksi pada penderita Diabetes Mellitus dan dapat menyebabkan periodontitis. Ada banyak faktor yang menjadi pencetus atau yang memperberat periodontitis, di antaranya akumulasi plak, kalkulus (karang gigi), dan faktor sistemik atau kondisi tubuh secara umum.

Rusaknya jaringan periodontal membuat gusi tidak lagi melekat ke gigi, tulang menjadi rusak, dan lama kelamaan gigi menjadi goyang. Angka kasus penyakit periodontal di masyarakat cukup tinggi meski banyak yang tidak menyadarinya, dan penyakit ini merupakan penyebab utama hilangnya gigi pada orang dewasa. Periodontitis merupakan komplikasi nomor enam terbesar di antara berbagai macam penyakit dan Diabetes Mellitus adalah komplikasi nomor satu terbesar khusus di rongga mulut. Sekitar $80 \%$ pasien Diabetes Mellitus memiliki masalah pada gusinya. Tanda-tanda periodontitis antara lain pasien mengeluh gusinya mudah berdarah, warna gusi menjadi mengkilat, tekstur kulit 
jeruknya (stippling) hilang, kantong gusi menjadi dalam, dan ada kerusakan tulang di sekitar gigi, pasien mengeluh giginya goyah sehingga mudah lepas. ${ }^{2}$

Tujuan studi kasus ini adalah untuk menjelaskan bahwa terdapat hubungan yang saling berkaitan erat antara peningkatan kadar glukosa dalam darah yang tinggi dengan periodontitis, dimana salah satu manifestasi klinis di rongga mulut yang dijumpai pada penderita DM adalah terjadinya peradangan pada jaringan periodontal.

\section{LAPORAN KASUS}

Tanggal 10 Mei 2019 seorang wanita usia 76 tahun datang ke Klinik Integrasi Rumah Sakit Gigi dan Mulut Universitas Jenderal Soedirman dengan keluhan gigi kiri atasnya goyang. Keluhan tersebut sudah dirasakan sejak beberapa bulan lalu, terasa goyang dan sakit saat digunakan untuk makan. Pasien mengaku memiliki riwayat penyakit Diabetes Mellitus dan penyakit jantung.

Pemeriksaan umum menunjukkan tekanan darah 130/70 mm/Hg, berat badan $51 \mathrm{~kg}$, dan tinggi badan $150 \mathrm{~cm}$. Hasil pemeriksaan gula darah sewaktu pada bulan April 2019 yang dibawa pasien saat ke periksa adalah $313 \mathrm{mg} / \mathrm{dl}$. Hasil ini menunjukkan nilai yang tinggi dibandingkan nilai normal.

Pemeriksaan ekstraoral secara inspeksi menunjukkan tidak adanya kelainan. Pemeriksaan intraoral dilakukan pada area yang dikeluhkan. Terdapat kegoyahan pada gigi 27 dengan derajat luksasi 3. Inspeksi dilakukan pada sekeliling rongga mulut dimulai dengan gigi yang dikeluhkan. Gigi 27 tidak mengalami karies dengan vitalitas $(+)$, perkusi, (-), palpasi (-), terdapat resesi gingiva $6 \mathrm{~mm}$, probing depth $4 \mathrm{~mm}$, dan debris di sekeliling gigi. Terdapat sisa radiks pada anterior rahang bawah dan karies pada hampir seluruh gigi tersisa, oral hygiene pasien cenderung buruk. Pasien mengkonsumsi obat Metformin dan Glibenclamide, tetapi pasien mengakui tidak teratur mengkonsumsi obat tersebut.

Diagnosis kerja pada kasus ini adalah periodontitis kronis gigi 27, tidak terdapat karies dan gigi vital, debris menumpuk pada area yang dikeluhkan, dan gula darah pasien yang sangat tinggi. Terapi yang diberikan berupa edukasi mengenai pengaruh kondisi gula darah yang tinggi terhadap kondisi gigi dan mulut, serta diberikan surat rujukan yang ditujukan kepada dokter spesialis penyakit dalam. Pasien diminta untuk kontrol 1 minggu kemudian.

Satu minggu kemudian pasien datang kembali untuk kontrol. Pemeriksaan umum menunjukkan tekanan darah 130/70 mm/Hg. Pasien telah melakukan cek gula darah kembali di bulan Mei 2019. Hasil pemeriksaan gula darah puasa adalah $203 \mathrm{mg} / \mathrm{dl}$.

Pemeriksaan intraoral dilakukan dan keadaan rongga mulut masih dalam kondisi yang sama dan karena hasil cek gula darah puasa pasien masih tinggi, maka pencabutan gigi 27 ditunda. Pasien kembali di edukasi untuk terus mengkonsumsi obat dan mengatur diet makanan (gambar 1 dan 2).

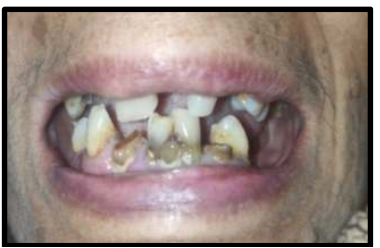

Gambar 1. Kondisi Rongga Mulut Pasien

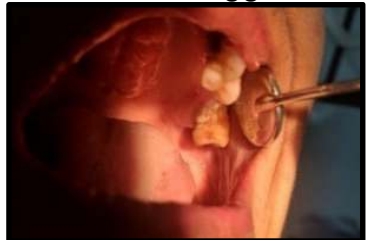

Gambar 2. Gambaran klinis gigi 27

\section{PEMBAHASAN}

Penyakit periodontal secara umum disebabkan oleh bakteri plak yang terdapat pada permukaan gigi. Plak merupakan deposit lunak berupa lapisan tipis biofilm yang berisi kumpulan mikroorganisme patogen seperti Porphyromonas gingivalis, Actinobacillus actinomycetemcomitans, Prevotela intermedia, Tannerella forsythia serta Fusobacterium nucleatum. Bakteri memiliki kemampuan dalam mendegradasi jaringan dengan cara menghasilkan beberapa produk bakteri seperti kolagenase, protease, hialuronidase, kondroitin sulfatese serta lipopolisakarida dan asam lipotheikholik.3.4

Periodontitis merupakan salah satu dari enam komplikasi DM. Sejumlah penelitian menunjukkan bahwa keparahan penyakit periodontal meningkat pada penderita DM dibandingkan pada individu yang sehat."1 Beberapa peneliti menyatakan bahwa keparahan penyakit periodontal pada penderita DM dipengaruhi oleh penurunan respon imun. Perubahan vaskuler yang terjadi menunjukkan adanya peningkatan aktivitas kolagen serta perubahan respon dan kemotaksis dari Polimorfonuklear (PMN) terhadap antigen plak, sehingga menyebabkan fagositosis terhambat. ${ }^{3}$

Penelitian yang dilakukan Bridge dkk menunjukkan bahwa keparahan periodontitis pada penderita DM lebih besar dibandingkan penderita non DM terutama dengan kontrol glikemik yang buruk, hal ini tampak pada peningkatan kedalaman probing, indeks plak, indeks gingiva, kerusakan attachment serta kehilangan gigi. ${ }^{6}$ Keadaan DM menyebabkan terjadinya penurunan fungsi PMN yang bisa meningkatkan derajat keparahan destruksi jaringan periodontal. Manifestasi DM didalam rongga mulut dapat berupa peradangan jaringan periodontal atau periodontitis. ${ }^{4}$ 
Peningkatan kadar glukosa darah (hiperglikemia) pada penderita DM menyebabkan komplikasi berupa mikrovaskuler yang ditandai dengan peningkatan AGE (Advanced glycation endproduct) pada plasma dan jaringan. Advanced glycation end products (AGEs) terbentuk akibat panas dalam proses pengolahan makanan, sebagai reaksi spontan antara gula dengan protein atau lemak; diperkirakan terbentuk akibat kondisi hiperglikemia dalam diabetes. AGEs adalah hasil endogen interaksi nonenzimatik glukosaprotein; struktur yang sangat reaktif, merupakan bahan oksidatif yang semakin penting untuk diperhatikan sebagai faktor risiko potensial kerusakan sel B-pankreas, resistensi insulin perifer, dan diabetes. ${ }^{5}$

Sekresi dan sintesis sitokin yang diperantarai oleh adanya infeksi periodontal, memperkuat besarnya respon sitokin yang dimediasi AGEs atau sebaliknya. Advanced glycation end-product yang terbentuk dapat terjadi pada protein, lipid dan asam nukleat. Pembentukan AGE pada protein, menyebabkan rantai silang antara polipeptida kolagen dan menangkap plasma non glikosilasi atau protein interstitial. Pengendapan low density lipoprotein (LDL) terjadi pada pembuluh darah besar dan deposit kolesterol di intima. Advanced glycation end-product menyebabkan terbentuknya rantai silang kolagen tipe IV membran basalis, yang berakibat melemahnya interaksi kolagen dan komponen matriks lain (laminin, proteoglikan), menghasilkan jejas pada struktur dan fungsi membran basalis. 7.8

Keadaan hiperglikemia akan menimbulkan AGEs, yang kemudian berinteraksi dengan RAGE(Receptor for AGE) pada endotel sehingga menimbulkan stres oksidatif, sebagai akibatnya akan terjadi gangguan pembuluh darah pada jaringan periodontal. Gangguan pembuluh darah akan menyebabkan gangguan distribusi nutrisi dan oksigen pada jaringan periodontal, sehingga bakteri gram negatif anaerob yang merupakan bakteri komensal pada poket periodontal akan menjadi lebih patogen. Gangguan pembuluh darah juga akan mempengaruhi pembuangan sisa metabolisme dalam jaringan periodontal, sehingga akan terjadi toksikasi jaringan periodontal dan gingiva. ${ }^{9}$

AGEs juga mengadakan ikatan dengan reseptor bermacam-macam sel seperti endotelium, monosit, makrofag, limfosit dan mesenkim. Ikatan ini menyebabkan aktivitas biologik seperti emigrasi monosit, pembebasan sitokin dan faktor pertumbuhan oleh makrofag, peningkatan permeabilitas endotelial, peningkatan aktivitas prokoagulan sel endotel dan makrofag, peningkatan proliferasi dan sintesis matriks ekstraseluler oleh fibroblas dan sel otot halus. Efek ini menyebabkan peningkatan komplikasi DM.
Kondisi-kondisi tersebutlah yang akan menyebabkan terjadinya periodontitis. 8

Dalam merawat pasien penderita Diabetes Mellitus perlu memperhatikan jadwal kunjungan. Pasien dengan Diabetes Mellitus sebaiknya menerima perawatan gigi di pagi hari. Sebelum perawatan dimulai pasien dapat melakukan pemeriksaan kadar gula darahnya terlebih dahulu. Jika kadar gula darahnya lebih rendah dari normal, maka pasien dianjurkan untuk mengkonsumsi sedikit karbohidrat sebelum perawatan untuk menghindari terjadinya hipoglikemia. Setelah pasien ada dalam kondisi normal, dapat dilakukan perawatan periodontal seperti scalling maupun perawatan bedah mulut berupa ekstraksi pada gigi-gigi dengan kegoyahan tinggi. Pasien juga diinstruksikan untuk selalu meminum obat diabetes oral dan menjaga diet makanan.

Kesimpulan dari laporan kasus ini adalah penyakit periodontal dapat dipengaruhi oleh Diabetes Mellitus dan periodontitis merupakan salah satu manifestasi Diabetes Mellitus di rongga mulut. Keparahan periodontitis terjadi akibat peningkatan kadar glukosa darah yang tidak terkontrol.

\section{DAFTAR PUSTAKA}

1. American Diabetes Association (ADA). Diagnosis and Classification of Diabetes Mellitus. 2011. Diakses pada 18 Maret 2021 dari:www.care. diabetesjournals.org Lcontent/34/Supplement_1/S62.full

2. Lubis I. Manifestasi Diabetes Mellitus pada Rongga Mulut. 2014

3. Falinda, D. Kontrol Infeksi dalam Kedokteran Gigi: Penatalaksanaan Poket Periodontal dengan Terapi Oksigen. Stomatognatic-Jurnal Kedokteran Gigi, 2015; 7(2), 74-78.

4. Newman, M. G., Takei, H., Klokkevold, P. R., \& Carranza, F. A. (2018). Newman and Carranza's Clinical Periodontology E-Book. Elsevier Health Sciences..

5. Mulyati S. 2016. Peranan Advanced Glycation End-products pada Diabetes. CDK-241/ 2016; 43: 6.

6. Ermawati, T. Hubungan Kadar Glukosa Darah dengan Pertumbuhan A. Actinomycetemcomitans pada Tikus Diabetes Melitus. Stomatognatic-Jurnal Kedokteran Gigi, 2015; 9(1), 19-22.

7. Surachman, A., Paramita, M., \& Kurniawan, A. A. Laporan Kasus: Manajemen Perawatan Gigi pada Pasien dengan Periodontitis Kronis disertai Diabetes Mellitus. Stomatognatic-Jurnal Kedokteran Gigi, 2019; 16(1), 1-6.

8. Rodrigues DC., Taba M., Novaes AB., Souza SLS., dan Grisi MFM., Effect of NonSurgical Periodontal Therapy on 
Glycemic Control in Patiens with Type 2 Diabetes Mellitus, J. Periodontol, 2003; 74 (9):1361-79

9. Ermawati, T. Periodontitis dan Diabetes Melitus. Stomatognatic-Jurnal Kedokteran Gigi, 2015; 9(3), 152-154.
10. Hikmah, N., Amandia D. P. Peran RANKL pada proses resorpsi tulang alveolar kondisi diabetes. Stomatognatic-Jurnal Kedokteran Gigi 2013, 10(3), 105-109. 